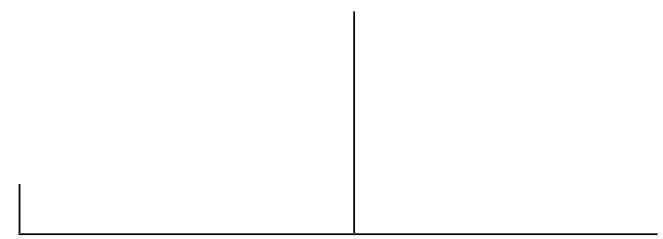

Rev. Latinoam. Psicopat. Fund., São Paulo, 16(3), 468-471, set. 2013

Atitudes raciais de pretos e mulatos em São Paulo Virgínia Leone Bicudo, Marcos Chor Maio (Orgs.). São Paulo: Editora Sociologia e Política, 2010.

\title{
A menina negra com o bebê branco no colo
}

Guilherme Gutman*

Folheando a dissertação de mestrado de Virgínia Leone Bicudo (1910-2003) - tornada livro por Marcos Chor Maio - eu usufruía livremente da ludicidade que esse antigo (e longevo!) formato de leitura é muitas vezes capaz de proporcionar. Passava os olhos pela bibliografia, tateava as páginas da edição, escutando o estalo seco das folhas viradas e sentia o "cheiro de livro novo". Olhava as fotos com curiosidade pelos personagens: os pioneiros da psicanálise em São Paulo, os familiares da autora e ela mesma, em retratos de infância, de juventude e de maturidade que ilustraram generosamente a demasiadamente humana tentação de montar uma linha cronológica e explicativa de como foi se desdobrando a vida de nossa personagem. Em outras palavras, diante das fotos, e estimulados pelo caráter biográfico da introdução (a cargo do organizador do volume), qualBrasil)

*Pontifícia Universidade Católica do Rio de Janeiro - PUC-RJ (Rio de Janeiro, RJ, 
quer leitor já estará enlaçado pela empreitada de pensar um pouco sobre Virgínia Bicudo; sobre o relevo acidentado do início de sua trajetória, assim como sobre as marcas que ela imprimiu a um lócus que articula as ciências sociais à psicanálise.

Só quando eu já havia realizado uma primeira leitura do livro que, ao retornar às fotos, me detive em uma delas, na qual, no canto inferior esquerdo, foi possível notar, em números desalinhados, a inscrição "1929”.

A foto me atinge - não há dúvida - não tanto pelo retrato em branco e preto das memórias em sépia que, embora me sensibilizem, não são as minhas. Tampouco pela gravura social da família em torno do pai negro, apadrinhado na grande São Paulo pelo "coronel" da fazenda de café (Campinas) na qual nasceu, com a mulher branca de ascendência italiana (Sicília) e com seus cinco filhos. Todas as questões sociológicas e etnográficas concernentes a essa família são, pela riqueza de sua composição, de enorme interesse para aquilo que uma certa historiografia registra como um capítulo importante na formação do "povo brasileiro". Neste sentido, impossível não notar neste retrato o modelo tradicional das fotos de família de inícios do século passado: o pai, em seus melhores trajes - sapato envernizado, paletó escuro, gravata-borboleta e lenço na lapela -, o único sentado, dirige à câmera um ar grave; ladeado pela esposa e pelos filhos, pousa para o fotógrafo naquilo que parece ser o quintal da casa em que viviam na Vila Economizadora. Difícil não notar, também, o equilíbrio instável do conjunto, patente no contraste duro das aspirações - e das realizações moderadas - de ascensão social contra as paredes nuas e manchadas da casa operária do bairro da Luz (SP).

Mas quando olho para a foto, o que me punge é a menininha de laços de fita na cabeça, quase defronte ao pai, e que abraça resoluta um desses bebês de plástico, branco como a sua mãe; pela legenda, fico sabendo que se trata de Carmem, irmã caçula de Virgínia Bicudo. Como saber, para além das análises sociológicas, o que exatamente torna tocante a menina negra abraçada ao seu precioso bebê branco? Tal qual na célebre proposição conceitual de Roland Barthes - em La chambre claire (1980) - reconheço nisto um punctum. E seu livro, entrelaçando dois elementos específicos e potencialmente presentes em fotos, Barthes diferencia o caráter mais consciente, ou racionalizado, de um dado modo de perceber uma imagem, de um outro modo que "vem quebrar (ou escandir)" o primeiro. Este segundo elemento, prossegue Barthes, "parte da cena, como uma flecha, e vem me transpassar (...) O punctum de uma foto é esse acaso que, nela, me punge (mas também me mortifica, me fere)".

Tomando de empréstimo os termos de Barthes, revela-se a questão que é a de que algo do punctum traz à luz, com uma veracidade única, algo que escapa ao olho treinado, culto ou acadêmico. Talvez porque o que ele faz aparecer não guarde relação com reflexões ou ilações de pensamento; estas poderão comparecer com um pequeno delay, neste caso fundamental, onde após atingidos por algo 
que salta da foto, nos pomos a pensar sobre o que se tenha passado e sobre as suas possíveis relações com toda investigação teórica possível do contexto que o retrato evoca.

Nesta dobra das reflexões conscientes por sobre o impacto experimentado, é mister ressaltar as interseções entre o fato da autora não ser indiferente ao tema que aborda - ou mais do que isso, ter sido visceralmente atingida por aquilo sobre o qual se debruça. Também é preciso dar o necessário relevo à utilização, por parte da autora, de instrumentos teóricos sociológicos e antropológicos da Escola de Pierson, e ao fato de que, à altura da redação de sua dissertação de mestrado, ela já estar envolvida pela psicanálise. Artificialmente, teríamos dois momentos distintos: um primeiro no qual Virgínia Bicudo experimenta na própria carne as vicissitudes de ser negra no Brasil; num segundo momento - ainda que indiretamente, pela via da fala de seus entrevistados -, ela "pensa" os efeitos dessa condição pelo modo de vida dos sujeitos que de alguma forma se defrontam com a sua negritude.

O problema fundamental é o de que, ao notar que os sujeitos entrevistados foram atingidos pelos constrangimentos racistas a que foram submetidos ao longo de suas vidas, conciliar as teorias sociológicas à possibilidade de que tais experiências vividas possam ter tido valor de causalidade psíquica na produção de quadros de sofrimento mental. É neste ponto que a psicanálise poderia, quem sabe, ter feito a sua entrada, procurando dar estofo teórico à construção de um caminho de compreensão de por que - para formulá-lo em palavras simples - as pessoas podem adoecer a partir da autodepreciação étnica.

Mas a psicanálise não entrou - pelo menos não de modo explícito - e que enorme tarefa Virgínia Bicudo teria pela frente caso houvesse pretendido enlaçar, neste contexto específico, a psicanálise à pesquisa antropológica! Seu livro Nosso mundo mental - tem como ponto de origem a leitura psicológica de "diversas situações da vida cotidiana, trabalho este que em sua quase totalidade foi apresentado em 1950 pela Rádio Excélsior (...). Em 1951, aqueles programas foram publicados pela Folha da Manhã em uma série de artigos" (Bicudo, 1956, p. 12). Com o espírito evidente de divulgação científica, ainda há grande hesitação quanto à possibilidade de articulação entre o seu conhecimento de psicologia e de psicanálise às questões do sofrimento mental relacionado à negritude em um país de elite branca e racista. ${ }^{1}$

${ }^{1}$ Para o leitor interessado, vale aqui a menção a uma empreitada onde essa articulação acontece: trata-se do livro Tornar-se negro: as vicissitudes do negro em ascensão social, da também psicanalista e negra Neusa Santos Sousa. 
Em outras palavras, Virgínia Leone não procurou resolver na teoria aquilo que, na prática, ela e tantos outros podem ter experimentado na vida.

A trilha de Virgínia Leone foi outra: saiu de uma situação socioeconômica desfavorável; deixou um belo e importante trabalho antropológico ligado à questão negra; formou-se psicanalista e participou ativamente da implantação da psicanálise em São Paulo e, por fim, talvez tenha trabalhado intimamente aquilo que, como se sabia, lhe cortava a carne.

\section{Referências}

Barthes, R. (1984). A câmara clara: nota sobre a fotografia. Rio de Janeiro: Nova Fronteira.

Bicudo, V. L. (1956). Nosso mundo mental. São Paulo: Instituição Brasileira de Difusão Cultural.

Sousa, N. S. (1983). Tornar-se negro: as vicissitudes do negro em ascensão social. Rio de Janeiro: Graal.

\section{Guilherme Gutman}

Médico e Psicanalista; Professor adjunto do Departamento de Psicologia da Pontifícia Universidade Católica do Rio de Janeiro - PUC-Rio (Rio de Janeiro, RJ, Br).

Rua Visconde de Pirajá, 595/905 - Ipanema 22410-003 Rio de Janeiro, RJ.

Fone: (21) 3026-0064

e-mail: guilhermegutman@gmail.com 